\title{
Textural Studies of some Granites and Gneisses from the Precambrian Vijayan Complex of Sri Lanka
}

\author{
K. DAHANAYAKE AND H. A. H. JAYASENA \\ Department of Geology, University of Peradeniya, Peradeniya, Sri Lanka.
}

(Date of receipt: 15 October 1982$)$

(Date of acceptance: 30 May 1983)

\begin{abstract}
Microcline rich gianites and gneisses occur abundantly in the Precambrian Vijayan Complex of Sri Lanka. These bodies forming the cores of plunging domes and folded structures show abrupt and gradational contacts with the country rocks. Textural studies of granites and gneisses reveal magmatic and metasomatic origins for these bodies.
\end{abstract}

\section{Introduction}

The Precambrian of Sri Lanka consists of metamorphic and igneous rocks belonging to three divisions:- Highland Group, Southwest Group and Vijayan Complex. ${ }^{4}$ Highland Group consists of metasedimentary and metavolcanic rocks such as quartzites, marble, granulites, gneisses and charnockites. Southwest Group is formed of calciphyres, quartzites, cordierite gneisses and charnockites. Vijayan Complex terrain is underlain by granites, granitic gneisses, hornblende biotite gneisses, migmatites, calc gneisses, quartzites and doleritic bodies. The structure of the Highland Group of rocks is characterized by overturned parallel, upright and double plunging folds. These rocks as well as those of the Southwest Group show a consistent linear structural trend. The structure of the Vijayan terrain is very complex and is dominated by plunging domes, synforms and antiforms (Figure 1).

So far, not much petrological work has been carried out on the Vijayan rocks and the available papers deal mostly with the interrelationship between the Vijayan Complex and the Highland Group. Vijayan Complex terrain has long been regarded as the basement on which Highland Group sediments had been deposited 1,3,7.8 Cooray 5 considered the Vijayan as amphibolite facies rocks formed due to migmatisation and granitization of pre-existing granulite facies Highland Group. Age data ${ }^{6}$ seems to confirm a period of cooling and uplift concurrent with migmatization and granitization, about $1150 \mathrm{Ma}$ ago, when perhaps some of the charnockites of the Highland Group were also formed.

The western boundary between Highland Group and Vijayan Complex is represented by a passage of metasediments into dominantly gneissic, granitic and migmatitic terrain. However in the east, the contact is demarcated by shearing at points along the course of Mahaweli river ${ }^{14}$ and this structural feature extends into the 

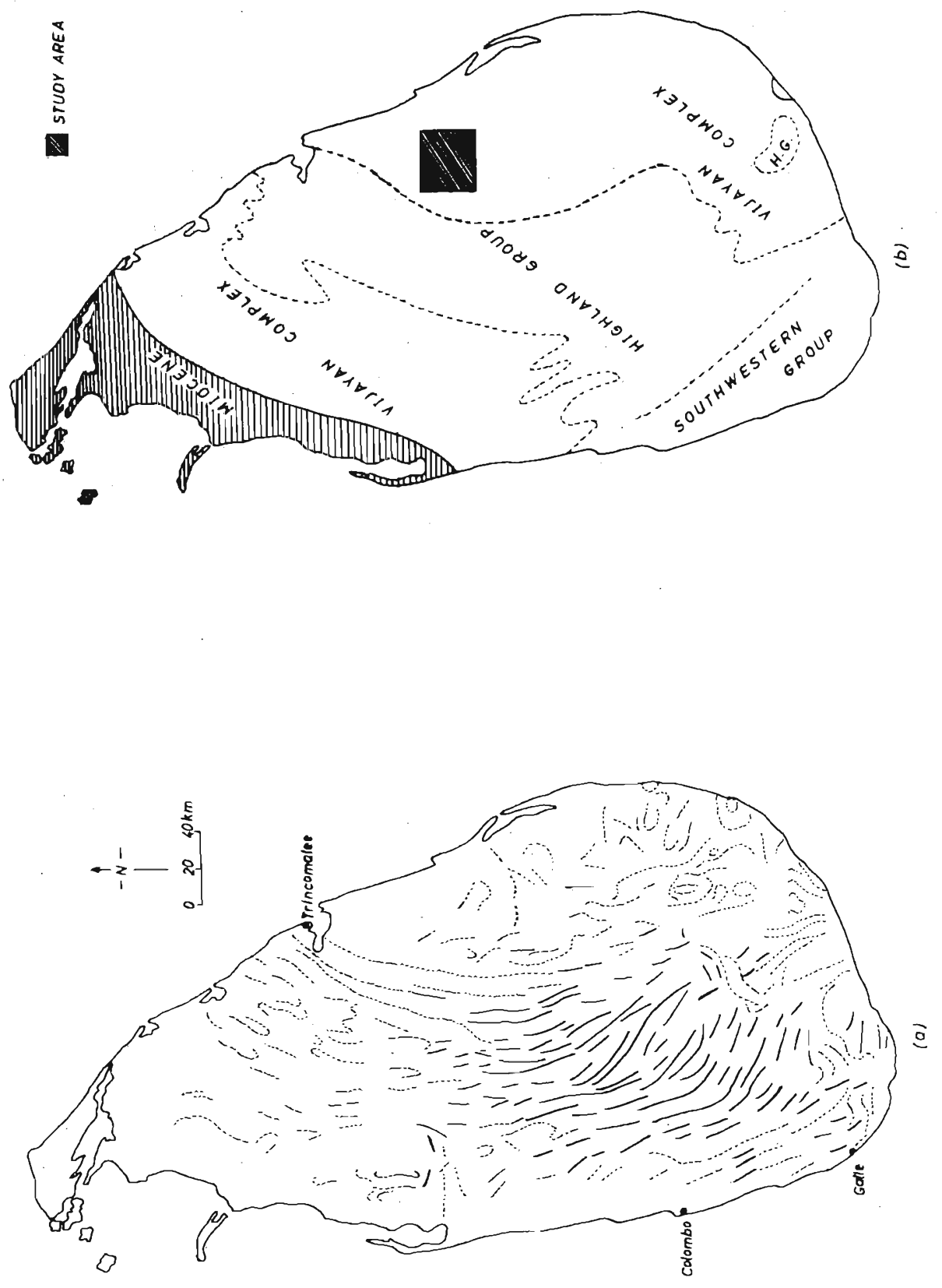
northeast towards a deep submarine canyon. ${ }^{2}$ The contact zone is characterized by a train of hot water springs and a series of basic intrusions. 12 The same authors recognized a Precambrain plate boundary at the contact zone where sediments and volcanic deposits had been metamorphosed consequent to collision of eastern and western Vijayan "plates".

In this paper the writers discuss the petrology and textural characteristics of granites and granitic gneisses with a view to understand the complex geological history of these rocks. For this purpose, an area of about $1000 \mathrm{~km}^{2}$ from the Vijayan Complex was selected in Eastern Sri Lanka (Figure ib).

\section{Methods of Study}

The aerial photographs of the area on the scale of $1: 20,000$ were studied for structural observations. Laboratory studies were supplemented by field mapping of the area on the scale of $1: 63,360$. The laboratory and field observations were computed to produce a geological map of a smaller scale (Figure 2) so as to obtain a better structural and geological picture of the area. About 40 thin sections from granites and gneisses of the area were studied for their petrology and texture.

\subsection{General Geology of the Study Area}

The study area forms a vast peneplained surface interrupted by isolated inselberg type ridges rising to about $150 \mathrm{~m}$ above MSL and sluggish streams, prominent among them in the area being Maduru Oya. The area is characterized by north plunging dome and antiform/synform structures. The cores of domes and folds are formed of microcline granites and gneisses which pass laterally into either migmatites or augen gneisses. These lithologies underlie mostly the rounded hills, isolated massifs and elongated ridges whereas hornblende biotite gneiss - the dominant rock type of the area - form most of the peneplained surface. Thin bands of calc gneiss, amphibolite, quartzite are found interbanded with homblende biotite gneiss which is often associated with silllike thick pegmatitic bodies.

The contact of microcline granites and gneisses with the surrounding migmatites and augen gneisses can either be abrupt or gradational. At abrupt contacts, the granitic body shows a shattered appearance with as many as five joint systems and mylonitic breccia is also associated. Pockets of hornblende are also noted at the contact area and silicified potash feldspar occurs within the cracks and joints of both the intrusion and the country rock. At gradational contacts which are more common, schlieren structures of basic to intermediate compositions are seen to grade into migmatites and gneisses. 


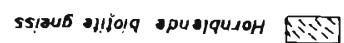

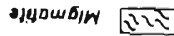

ss/ous uasny 710

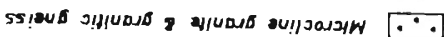

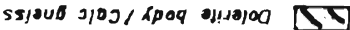

Uก/AกIIV $:=$

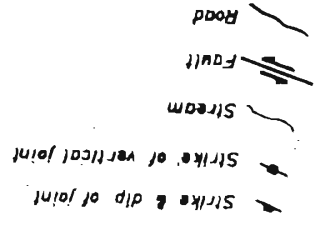

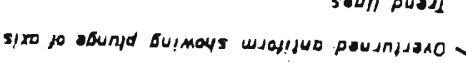

5ixo jo sefunja suimoys mej!jur

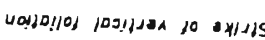

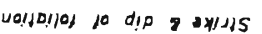

(q)

wyzl !

(D)
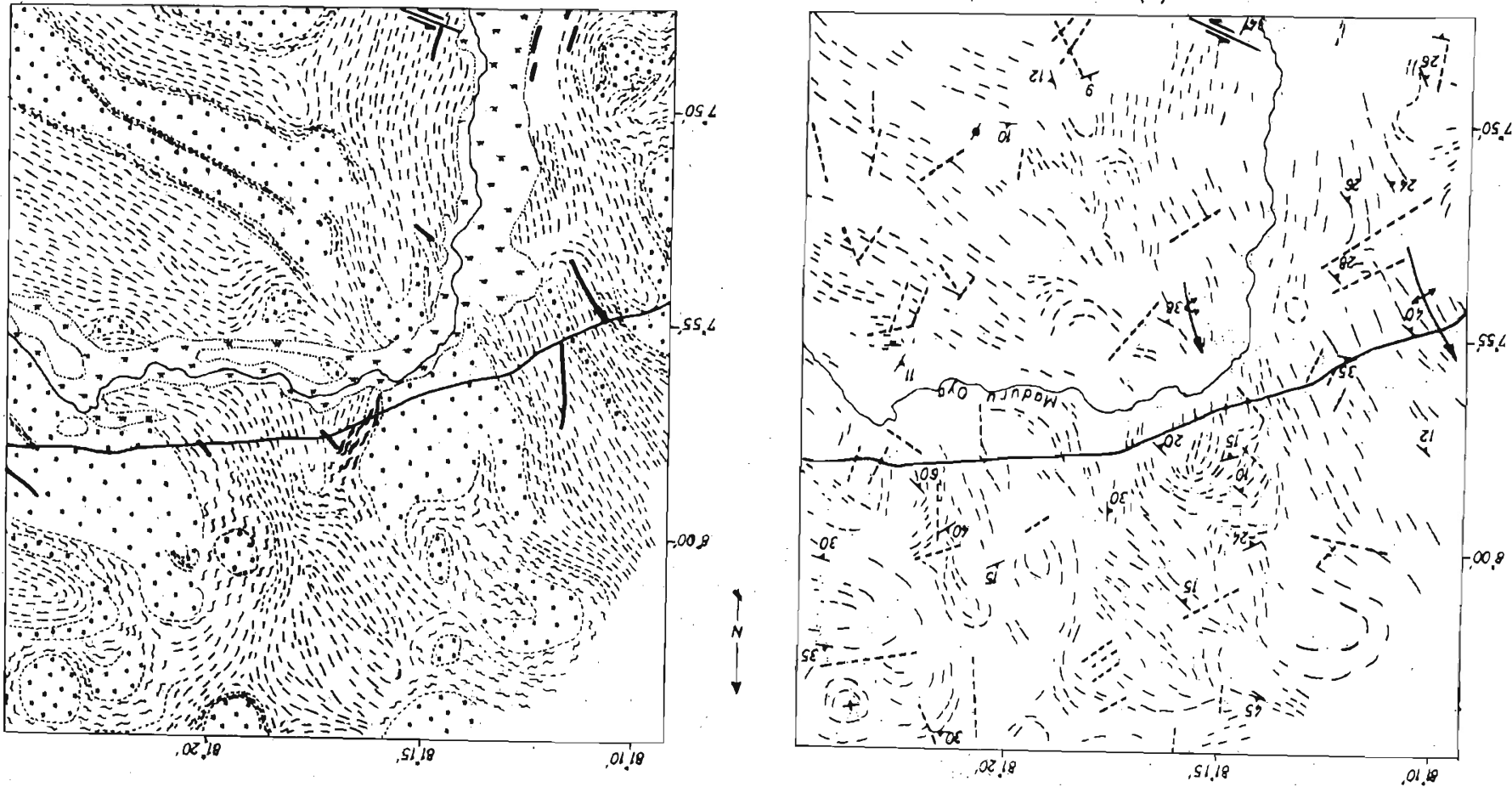


\subsection{Textures of Granites and Gneisses (See Figures 3 \& 4)}

The granites and gneisses of the study area consist mainly of microcline, plagioclase and quartz in that order of abundance with subsidiary biotite, hornblende, magnetite and apatite. The granites are generally coarse grained and when the gneissic character is well defined the rock tends to be medium grained with biotite and hornblende aligned parallel to local foliation. Pegmatitic aggregates are found along and across foliation. Most of the granites and gneisses fall under the granite or quartz syenite fields of the classification of Streckeisen (1967).

Microcline with sizes ranging from 0.5 to $3 \mathrm{~mm}$ occurs dominantly in the granites and gneisses as independent grains and perthitic intergrowths or it is observed in association with plagioclase. Cross hatched twinning is present prominently in microcline which occurs as anhedral grains locally clustered in patches and interstitial to large plagioclase grains. When in contact with plagioclase, microcline is found to protrude into the former as tongues and lobes. Plagioclase replaced by a cross hatched microcline phase is common in the rocks studied and diffused margins characterize the microcline plagioclase contact. Sometimes, ghost plagioclase twins are observed in microcline. The early plagioclase grains surrounded by microcline show deformed twins and sericitization products riddled inside them. Microcline at points occur as tiny blebs in plagioclase giving a pseudo-antiperthitic texture. At the interfaces of larger microcline grains, intergranular albite is observed as the double row variety or the wart shaped type. At microcline plagioclase boundaries, swapped rims of albite are observed. A whole range of perthitization products from the incipient type to the dominantly exsolved phase is characteristic of the granites and gneisses. Thus string, flame and rod type perthites are commonly observed. The perthitic growths are intense at the cores of domes and at points of shear such as the contacts of augen gneiss bodies. Granulated guartz is closely associated with such growths. Bleb-like perthites bear a resemblance to the swapped albitic rims in appearance whereas the braid type shows relict material similar to that in sericitized plagioclase grains.

Plagioclase grains range in size from 0.5 to $5 \mathrm{~mm}$ and are anhedral for the most part due to embayment by microcline and quartz. Idiomorphic quartz grains are occasionally observed in plagioclase grains. Three distinct types of plagioclases are noted. The early formed plagioclases are identified by their corroded character. They are often engulfed or cross cut by younger plagioclases whose compositions tend to be those of albite or oligoclase. The third type occurs as rims or integranular albite at plagioclase-microcline and microcline-microcline interfaces as referred to earlier. Plagioclase of earlier origin are found as inclusions in later formed grains. The early type possesses coarse albite twin lamellae and are sericitized with accessory muscovite, calcite and epidote. The most common twins in plagioclases are those of albite type. The twins are either coarse and rare or multiple with extremely fine lamellae. Both carlsbad and albite twinning are encountered together with occasional pericline twinning. Some albite twin lamellae characteristically extend all the way across the grains but terminate abruptly at fractures. Plagioclase forms borders and relict 

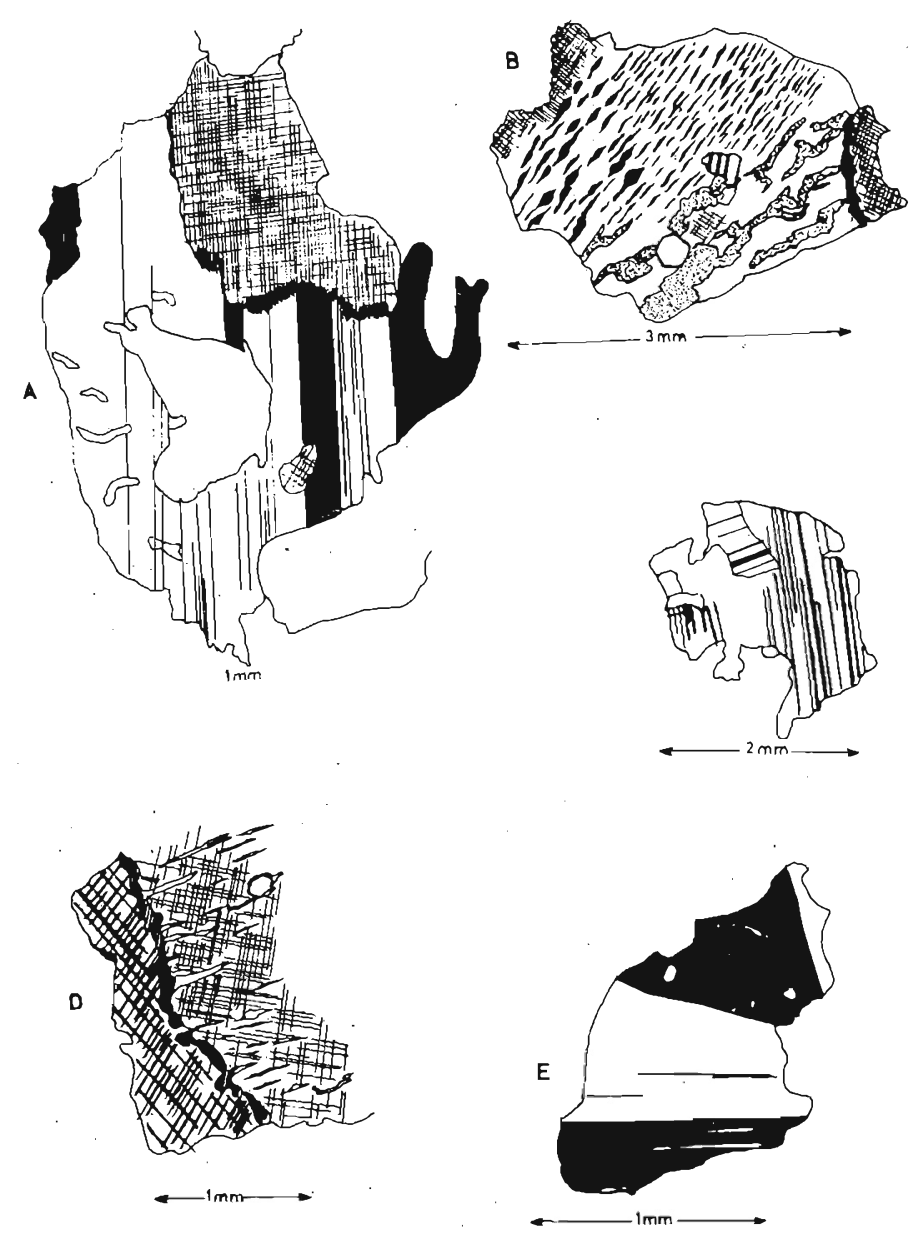

Figure 3: A - diffusive boundary between plagioclase and microcline (Sample No. MO/75)

B - development of perthites, relict plagioclase (in the centre) and sericitization (stippled) (Sample No. MO/6).

$\mathrm{C} \rightarrow$ two generations of plagioclase (Sample No. MO/96)

$\mathrm{D}$ - formation of intergranular albite (double row type - close ruled) (Sample No. MO/79)

E - Combined carlsbad - albite twinning (Sample No. MO/10). 

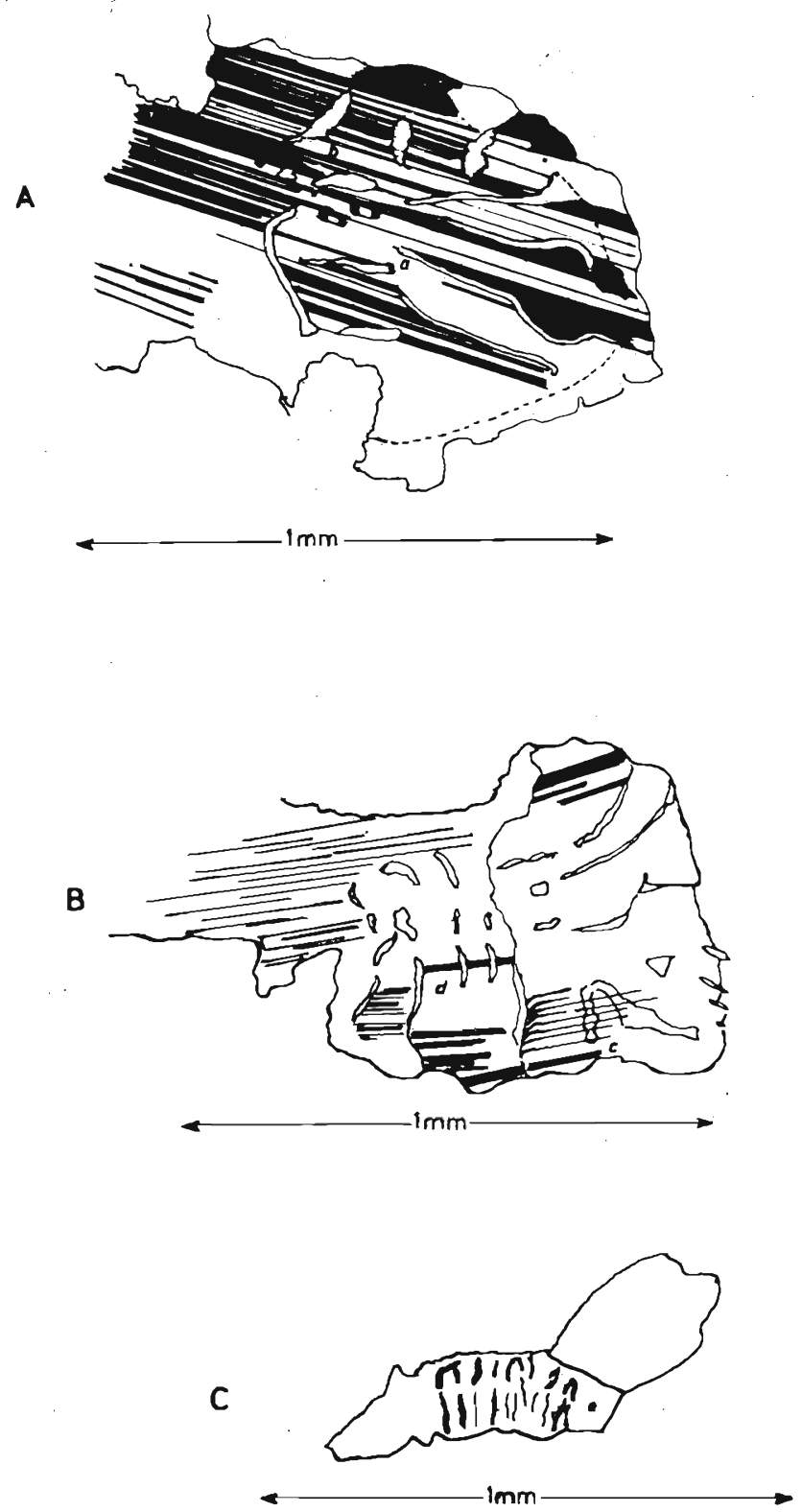

Figure 4: Development of different types of myrmekites.
A - (a) Type I
(b) Type II
B - (c) Type II
(d) Type III
C - (e) Type IV 
patches at the edges of microcline and at points narrow veinlets of pseudoperthite also are noted. Differently twinned enclaves of plagioclases are observed within later formed grains.

Quartz occurs as large $(0.5$ to $3.5 \mathrm{~mm})$ grains with smooth undulating borders. Biotite, hornblende and feldspar are found engulfed as patches in quartz grains. Quartz grains co-existing with perthitic microcline display faintly shattered margins. Two types of quartz are noted: one with hexagonal outlines and smooth boundaries occurring as inclusions in plagioclase; the other type is more abundant with irregular morphology and characteristic undulose extinction and such quartz grains embay the adjacent grains.

Three distinct types of myrmekites are noted in the rocks studied. In the type I, worm-like quartz rods have smooth margins at which twinning terminates abruptly. The type II occurs concurrently with secondary twin lamellae which are continuous without any separation being caused by myrmekitic quartz with sutured boundaries. The type III myrmekites show clear or diffusive boundaries and are usually distributed along the later formed cracks within plagioclase grains. The secondary twin lamellae are also observed to terminate in myrmekite development. A fourth indistinct type of myrmekite occurs as part of a reaction growth zone of plagioclase grains enclosed by microcline. Biotite is often associated with myrmekites.

In the rock types studied, biotite occurs as thin elongated grains and are often replaced by chlorite. Hornblende is often corroded and replacement products of biotite and chlorite are noted. Sillimanite has rarely been observed in the gneisses.

\section{Discussion}

The textures and mineral parageneses reported in this paper provide some information as to the intrusive and metasomatic relationships which had characterized the Precambrian Vijayan Complex rocks of Sri Lanka. The early history of the rocks of the study area is scantily known. Crawford and, Oliver ${ }^{6}$ considered Vijayan transformation to have taken place about $1150 \mathrm{Ma}$ within a preexisting lithology of granulite facies. The field studies in the area do indicate a metasedimentary sequence characterized by occurrences of hornblende biotite gneiss with rare sillimanite calc gneiss and thin quartzite bands implying perhaps an earlier Archean deep water marine facies.

Dome structures with cores formed of granites rich in mesoperthite suggest intrusive igneous activity at temperatures of well over $600^{\circ} \mathrm{C} \cdot .^{10}, 11,13$ The occurrence of broad twin lamellae of albite, carlsbad twinning and idiomorphic quartz inclusions in plagioclase seem to reflect the magmatic phase of domal granites. ${ }^{10}$ The petrological observations and age determinations, ${ }_{2}^{5,6}$ lend support to the existence of a relatively long period of cooling subsequent to the igneous phase. Such conditions were per- 
haps conducive to the non perthitic microcline development and replacement of plagioclase by microcline resulting in decalcification and sericitization. "Towards the later stages of cooling, the formation of myrmekites of type I and late albite rims could be envisaged. The cooling processes were probably interrupted by a deformational phase resulting in the growth of deformed twin lamellae. Consequently the cooling magmatic body had fractured initiating emanations of $\mathrm{K}$-rich fluids, which had seeped through cracks and joints of both the intrusion and the country rock. The ensuing $\mathrm{K}$-feldspathization would form microcline devoid of relict plagioclase along cracks within plagioclase grains and also perhaps initiated the replacement of plagioclase by microcline and the formation of types II and III myrmekites. The potash metasomatism could well have resulted in the granitization of rocks which are now observed to be perthite free or poor. Most of the granites forming folded structures are believed to be so originated. Field observations of schlieren structures also attest to the metasomatic character of such granites.

\section{Conclusions}

The textural studies of some granites and gneisses of the Vijayan Complex lead the authors to propose the following sequence of events.

(a) Intrusion of magmatic bodies probably about $1150 \mathrm{Ma}$ into a metasedimentary suite.

(b) Relatively long period of cooling characterized by plagioclase replacement, albite formation and myrmekite development.

(c) A period of deformation with the development of fine twin lamellae of plagioclase followed by fracturing of the cooling magmatic body and emanations of $\mathbf{K}$-rich fluids.

(d) Potash metasomatism at PT conditions characteristic of amphibolite facies with the formations of some granites. (probably a phase of retrograde metamorphism as indicated by the alterations; (a) hornblende $\rightarrow$ biotite and chlorite and (b) biotite $\rightarrow$ chlorite and muscovite.)

\section{Acknowledgements}

The authors wish to thank Miss Tara Tampoe for assistance in the laboratory. For drafting figures and typing the manuscript, grateful thanks are due to Mrs. Jayanthi Wijesekera and Mr. K. Dunuhappawa. 


\section{References}

1. ADAMS, F. D., (1929). The Geology of Ceylon, Canadian Jour, Research, 1: $425-511$.

2. BUSH, S. A. \& BUSH, P. A., (1969). Trincomalee and Associated Canyon: Deep Sea Research, V. 16, p. 655 - 660.

3. COATES, J. S., (1935). The Geology of Ceylon. Ceylon J. Sci (B), 19 (B): $101-187$.

4. COORAY, P. G., (1978). Geology of Sri Lanka. Third Regional Conference on Geology and Mineral Resources of SE Asia, Bangkok, Thailand 14 - 18, Nov. 1978, $701-710$.

5. COORAY, P. G., (1962). Charnockites and their associated gneisses in the Precambrian of Ceylon. Quart. Jour. Geol. Soc. London, 118: 239 - 273.

6. CRA WFORD, A. R. \& OlIVER, R. L., (1969). The Precambrian geochronology of Ceylon, Spec. Publ. Geol. Soc. Ausiralia, 2: $283-306$

7. FERNANDO, L. J. D., (1948). The Geology and Mineral Resources of Ceylon. Bull. Imp. Inst. London, 46: 303325.

8. KATZ, M. B., (1971). The Precambrian metamorphic rocks of Ceylon. Geol. Rundschau, 60: $1523-1549$.

9. MARMO, V., (1971). Granite Petrology (Elsevier) 244 p.

10. MEHNERT, K. R., (1968). Migmatites and the origin of Granitic Rocks (Elsevier)': 393 pp.

11. Michor, P., (1961). Struktur der Mesoperthile Neues Jahr. Miner, Abhandl., 96: 213 - 216.

12. MUNASINGHE, T. \& DISSANAYAKE, C. B. (1979). Is the Highland-eastern Vijayan boundary in Sri Lanka a possible mineralized belt? Econ. Geol. V. 74, p. $1495-1496$.

13. TUTTLE, G. F. \& BOWEN, N. L., (1958). Origin of granite in the light of experimental studies in the system $\mathrm{NaAlSi}_{3} \mathrm{O}_{8}-\mathrm{KALSi} \mathrm{O}_{8}-\mathrm{SiO}_{2}-\mathrm{H}_{2}$ ) Geol. Soc. of America. Memair 75: $154 \mathrm{pp}$.

14. VITANAGE, P. W. (1972). Post Precambrian uplifts and regional neotectonic movements in Ceylon. 24th Intem. Geol. Congr. Sec. 3: $642-654$. 